\title{
Economics and demographics constrain investment in Utah private grazing lands
}

\author{
REGINA PETERSON AND D. LAYNE COPPOCK
}

Authors are former graduate research assistant and associate professor, Department of Rangeland Resources, Utah State University, Logan, Utah 843225230. The current address for Peterson is c/o HQ USAR EUR, CMR 420 Box 44, APO AE 09063. The correspondence co-author is Coppock.

Abstract

In Utah during the early 1990s it was theorized that substantive change was under way in the management of private grazing land. Change was thought to be spearheaded by grazing permittees who feared losing access to public forage and thus wanted to increase carrying capacity of private grazing land as a hedging tactic. We synthesized results from socioeconomic surveys conducted among a target population of 5,067 grazing livestock producers during 1993, 1996, and 1997. This population was evenly divided between permittees and operators wholly dependent on private grazing (e.g., private operators). Our primary objectives were to: (1) test the hypothesis that a sustained upswing in management change was occurring; (2) identify factors associated with operations that "actively" invested in their properties versus those that were "passive"; and (3) identify producer priorities for applied research. Mail and phone surveys were used. Data analysis included descriptive statistics and logistic regression. Compared to private operators, permittees controlled far more private land and livestock and were more profit-oriented and dependent on livestock-derived income. Managers of both groups were aged-37\% of the population was $>65$ years old. Eighty percent of 393 managers surveyed in 1996-7 classified their operations as passive and ranked factors related to aging and economics as main reasons for passivity. Logistic regression and ranking exercises revealed that the active minority was most associated with higher gross annual incomes, more stewardship values, greater willingness to incur debt, and being a permittee. Permittees were more inclined to be active managers because of a greater entrepreneurial orientation compared to private operators, who tended to be hobby ranchers. Our work supported an alternative hypothesis that passivity in land management has been maintained in Utah during the 1990s, largely because incentives were lacking for most of the population to do otherwise. A wealthier minority, however, could still make large investments in their operations because of a superior risk tolerance. We concluded that demographic and economic factors exert the most control over producer behavior today, not access to information or new technology. One consequence is that demand for information and technology can be episodic due to coincident economic, demographic, and policy factors, which also implies that applied research, extension, and policy formulation need to be more opportunistic in response to change. Producers felt that

Work was primarily supported under McIntire-Stennis project 907 of the Utah Agricultural Experiment Station (UAES) and this submission has been approved as UAES journal paper no. 7158. Other support was provided by project SW95-015 of the USDA Western Region Sustainable Agriculture Research and Extension (SARE) program, and project CX822801-01 of the US Environmental Protection Agency. Brenda Ralls and Susan Durham are especially thanked for assistance with statistics. Emma Young, Brenda Ralls, Betty Gregory, Floie Nelson, and Alan Birkenfeld are acknowledged for key contributions to data collection. Del Gneiting and his staff at the Utah Agricultural Statistics Service helped with sampling design for survey of private-land-only operators. We thank the 393 Utah land managers who participated in telephone surveys and another 148 who participated in mail surveys. Comments from anonymous reviewers improved the manuscript.

Manuscript accepted 19 Jun. 2000.

\section{Resumen}

A inicios de la década de los 90 's se teorizó que en Utah estaba ocurriendo un cambio substancial en el manejo de los pastizales privados. Se pensó que el cambio era liderado por los permisionarios de tierras de pastizal quienes temían perder el acceso al forraje público, así buscaron aumentar la capacidad de carga de los pastizales privados como una táctica de bloqueo. Sintetizamos los resultados de muestreos socioeconómicos conducidos durante 1993, 1996 y 1997 entre una población de 5,067 ganaderos. Esta población se dividió uniformemente entre permisionarios y operadores totalmente dependientes de pastizales privados (Por ejemplo, operadores privados). Nuestros objetivos principales fueron: (1) probar la hipótesis de que estaba ocurriendo un mejoramiento ascendente en el manejo. (2) identificar los factores asociados con las operaciones que invirtieron "activamente" en sus propiedades contra aquellas que estuvieron "pasivas" y (3) identificar las prioridades de los productores de investigación aplicada. Se utilizaron encuestas telefónicas y por correo. El análisis de los datos incluyó estadística descriptiva y regresión logística. Comparados con los operarios privados, los permisionarios controlaron mucho mas la tierra privada y el ganado, estaban mas orientados a tener ganancias y dependientes de los ingresos derivados del ganado. Los manejadores de ambos grupos eran personas viejas, $37 \%$ de la población tenia mas de 65 años. El 80\% de 373 manejadores encuestados en 1996-1997 clasificaron sus operaciones como pasivas y clasificaron los factores relacionados con la edad y económicos como la principal razón de la pasividad. La regresión logística y los ejercicios de clasificación revelaron que la minoría activa estuvo mas asociada con mayores ingresos brutos anuales, mas valores de administración financiera, mayor disponibilidad de contraer deudas y ser permisionario. Los permisionarios se inclinaron mas a ser manejadores activos por su mayor orientación empresarial, comparados con los operarios privados quienes tendieron ser ganaderos por pasatiempo. Nuestro trabajo soporta un hipótesis alternativa que la pasividad en el manejo de la tierra ha sido mantenida en Utah durante la década de los 90's, principalmente por la falta de incentivos para la mayoría de la población para hacer lo contrario. Sin embargo, una minoría adinerada pudo hacer grandes inversiones en sus operaciones debido a su tolerancia superior al riesgo. Concluimos que los factores demográficos y económicos ejercen el mayor control sobre el comportamiento actual de los productores y no el acceso a la información y nueva tecnología. Una consecuencia es que la demanda de información y tecnología puede ser episódica debida a factores económicos, demográficos y políticos, lo cual también implica que la investigación aplicada, extensión y formulación de políticas necesita ser más oportunista en respuesta al cambio. Los productores sintieron que la mejora en el forraje, políticas y lo económico fueron las necesidades de investigación prioritarias. Un pico aparente de retiros entre los propietarios tradicionales de la tierra presagia un cambio rápido y sustantivo en el uso de los pastizales privados de Utah. Casi un tercio de ellos esta planea un retiro y espera vender su propiedad a desarrolladores de terrenos. 
forage improvements, policy, and economics were top research priorities. A looming crest of retirements among traditional landowners bodes for substantive and rapid change in the use of Utah private grazing land. Nearly one-third of those planning retirement hope to sell property to land developers.

Key Words: ranching, hobby ranching, land use, technology transfer, sustainable agriculture

The early 1990s were a time of intense rhetoric advocating change in the management of public grazing lands (Workman 1994). This atmosphere increased fears among Utah grazing permittees that they would lose access to public forage. In 1993 it was estimated that $27 \%$ of Utah permittees planned to intensify use of private grazing land to compensate for anticipated loss of public grazing (Birkenfeld 1994, Coppock and Birkenfeld 1999). One consequence of this strategy was an apparent increase in producer demand for forage materials, grazing systems, and irrigation technology during the early 1990 s (Ralph Whitesides, Utah State University, pers. comm., 1995). Expert opinion from the field also supported the view that a revolution was under way in the use of Utah private grazing lands by 1994 (Karl Kler, NRCS, pers. comm., 1995).

It is important to understand how and why production systems change and the roles played by extension information, technology, policy, and economics. With this overall goal in mind, in 1996 we resurveyed permittees previously studied in 1993 (Birkenfeld 1994, Coppock and Birkenfeld 1999) and in 1997 we added a similar survey of Utah producers operating only on private land. Our major objectives were to determine: (1) whether substantive change in management of private grazing lands was occurring; (2) major causes and constraints for substantive change; and (3) producer priorities for applied research.

\section{Methods}

\section{Target Population and Sampling}

Grazing resources in Utah occur on public land (about $80 \%$ of the land area) and on a much smaller amount of privately owned land. Private land tends to be located in more mesic environments and thus typically have a higher grazing potential than public lands (Anderson 1989).

The target population for this research consisted of 2 sub-populations of grazing livestock producers: (1) those dependent on public and private grazing lands; and (2) those dependent only on private grazing lands. This target population is very diverse in terms of operation size, reliance on offranch income, and motivations for involvement in livestock production (Peterson 1997, Coppock and Birkenfeld 1999, Coppock and Peterson, unpubl. data, 1998).

The permittee sub-population consisted of 2,520 operators and all had access to private grazing land. The process of characterizing this sub-population is provided in Coppock and Birkenfeld (1999). Unlike permittees who were easily identified from public rosters, private-land-only operators (henceforth referred to as private operators) were identified from confidential census lists held by the Utah Agricultural Statistics Service (UASS). The UASS initially identified a potential pool of 6,192 operators relevant to our research. After deleting permittees and other land users extraneous to our objectives we had a subpopulation of 2,547 . It is possible that the Statistics Service sampling frame excluded private operators who have very few (i.e., <10) grazing livestock because such operators may not always be enumerated as agricultural producers (Delroy Gneiting, UASS, pers. comm., 1997). We thus acknowledge the possibility that omitting these operations could lend bias to our results, but we had no reasonable means to identify them. Overall, our target population for this study consisted of 5,067 operators, evenly divided between permittees and private operators.

The primary results reported in this paper came from telephone surveys of 192 permittees (Peterson 1997) and 201 private operators (Coppock and Peterson, unpubl. data, 1998). The survey of permittees occurred over 16 weeks from June through October 1996. The survey of private operators occurred over 6 weeks during October and November 1997. In all cases, phone calls were preceeded by an introductory letter that explained the purpose of the survey and requested voluntary participation. The survey of permittees was conducted by students at Utah State University (USU), while, for reasons of confidentiality, the survey of private operators was conducted by employees of Utah Agricultural Statistics Services. Differences in the time required to complete the surveying were partially attributable to effects of season-fall was an easier time than summer to locate respondents. The 192 permittees were randomly selected from 340 who had responded to a mailed survey in 1993. This pool of 340 respondents was an unbiased sample of the target population as judged from interviews of non-respondents. Details concerning the mailed survey can be found in Birkenfeld (1994) and Coppock and Birkenfeld (1999). The number of private operators sampled (i.e., 201) was intended to be similar to the number of permittees sampled to satisfy statistical design requirements (Susan Durham, USU, pers. comm., 1996). The overall sampling rate was $7.7 \%$ (i.e., 393 out of 5,067). Sample size was estimated to yield $95 \%$ confidence intervals having confidence limits within \pm 5 percentage points of sample means for binomial response variables (Scheaffer et al. 1979). The major sampling difficulty was getting in touch with respondents listed on the sampling frames. Once people were contacted the rate of survey completion was $>95 \%$ (Peterson 1997, Delroy Gneiting, UASS, pers. comm.). This indicated that operators were interested in communicating with us.

\section{Hypotheses and Structure of Surveys}

In $1993,32 \%$ of permittees were considered "active" managers who were attempting to adapt to anticipated changes in public land access, while 68\% were "passive" managers embracing a "wait and see," more risk-averse attitude. About four-fifths of active managers focused on intensified use of private grazing land to increase carrying capacity, while one-fifth focused on economic diversification (Birkenfeld 1994, Coppock and Birkenfeld 1999).

Previously cited anecdotal observations appeared to support the hypothesis that "range reform rhetoric", in conjunction with relatively high beef prices, was leading to widespread increases in the intensified use of private grazing lands throughout Utah in the early 1990s. Private grazing lands had previously been a relatively ignored production resource (D.L. Coppock, unpubl., 1995). This suggested that fundamental change in production practices could occur primarily as a result of socioeconomic pressure that would restrict the grazing resource base and force producers to invest in smaller acreage and become more efficient. That pressure can be a stimulus for technology adoption and improved production efficiency in agroecosystems was noted by Boserup (1965).

In contrast to predicting a continuous and widespread upswing in intensification, however, an alternative hypothesis was that producer interest in intensification would be episodic or ephemeral. For example, by the mid-1990s a waning of 
"Range Reform rhetoric," declines in beef prices (DeeVon Bailey, USU, unpubl. data, 1999), increased costs of inputs, continued aging of the producer population, and attractive investment options offranch may have forced a majority of operators to remain conservative and refrain from investing in their grazing operations. Only a minority would make good on plans to invest and intensify resource use. If confirmed, this would imply that producer attitude toward changing their production systems shifts back and forth depending on macro- and micro-level variables such as policy initiatives and economic incentives.

The test of these alternative predictions, and explaining why operators selected an active versus passive strategy, constituted the main thrust of this study. All survey respondents were lumped into active or passive categories and it was noted whether operators maintained fidelity to, or altered, strategy during the dynamic period of 1992-3 to 1996-7. Active operators were defined as all who were engaged in "substantive" forms of intensification, diversification, or extensification with their private-land operations (Peterson 1997). Intensification typically involved efforts to increase carrying capacity via forage improvements and irrigation systems. Diversification implied increasing the variety of income flows by investing in new on-ranch enterprises such as recreation concessions and/or exotic livestock. Extensification involved expanding the private land base for grazing. This primarily is done through land purchase, but leases and other forms of resource exchange also are used. Given the wide range of wealth in our target population, the definition of "substantive" was relative to the resources of each respondent. Substantive commitments involved dedication of monetary or other resource investments that were large and meaningful in the opinion of respondents. Passive operators were defined as all who were not active (Peterson 1997). This included operators who showed some form of inertia or resistance to investing in their operations. Sources of inertia or resistance included: (1) change being viewed as unnecessary; (2) change being viewed as too expensive or risky; (3) pending retirement; (4) desire to get out of ranching and to sell property and other assets; (5) operators planning to diversify off-ranch; and (6) desire to increase profit margins from livestock production by reducing inputs. Passive behavior has its own logical rationale. We therefore did not interpret pas- sive behavior in a negative sense compared to active behavior.

We hypothesized that compared to operations that were passively managed, those that were actively managed would tend to have larger scales of production and managers would tend to have higher incomes and more formal education (Rogers 1983, Coppock and Birkenfeld 1999). Larger operations were expected to be more dependent on income from livestock production and have more of a business orientation compared to smaller operations that are often dominated by hobby values and managers with substantial sources of offranch income (Coppock and Birkenfeld 1999). Finally, we expected overall that the sub-population of permittees would have a greater proportion of active managers compared to the sub-population of private operators. This was largely because the permittees should be more concerned about making private-land investments in anticipation of changes in public grazing policies (Peterson 1997). In this regard the sub-population of private operators served as a "control" group.

The phone survey for permittees consisted of 2 distinct sections. The first section had 20 questions that sought: (1) information on AUMs obtained from public land, including details on any recent cuts in AUMs; (2) confirmation of coping tactics in 1993 and 1996; (3) up to 3 ranked reasons to explain why the 1996 coping tactic was selected; (4) up to 3 ranked reasons to explain any change in coping tactics between 1993-6; (5) selfrankings [scaled from 1 (lowest) to 5 (highest)] to reveal the operator's level of confidence in the future, level of commitment to keeping operations going, level of willingness and ability to assume more debt to invest in their production systems, and suitability of their land holdings for technical improvement; (6) ranked opinions on roles of prices, weather, and politics on planning and management of operations; and (7) up to 3 ranked priority problems viewed as most critical for applied research. The second section of the survey had 10 options on color-coded sheets to make interviewing easier. One option would be filled out depending on coping tactic for 1996. For example, if an active tactic to intensify use of private grazing land was selected in the first section, the interview would proceed with 23 questions under option 6 in the second section that dealt with details of intensification plans. If a respondent noted a passive tactic to retire and sell off property in the first section, the interview would pro- ceed with 4 questions under option 2 in the second section that dealt with these details. Phone surveys varied in duration from 15 min to 1 hour with an average of $40 \mathrm{~min}$. Active tactics required more time to document than passive tactics. When questions required open-ended responses, in no instance were respondents coached or prompted by enumerators. A copy of the survey is in Peterson (1997). Again, detailed background information on 340 permittee operations had been previously collected with a mail survey by Birkenfeld (1994). To reduce the chance that phone survey would become too tedious, background information was not re-collected in 1996.

The 1997 phone survey for private operators was very similar to that used for permittees except for the following: (1) background information on production resources of operations and the goals, concerns, felt needs, gross annual income, age, and formal education of operators was collected in the first section of the privateoperator survey since these data had not been previously collected; (2) background information on management strategy 5 years earlier in 1992 was collected based on recall of respondents; (3) no information was sought on use of public land, since that was irrelevant; and (4) compared to the phone survey of permittees, the second section of the private operators survey was altered to make it more concise and manageable for enumerators. Design of the second version of the survey benefited from our experiences with the first version. As a result of adding questions to the first section and making the second section more concise, the overall time required to complete phone surveys for private operators was nearly identical to that for the permittee survey (Delroy Gneiting, UASS, pers. comm., 1998).

\section{Data Analysis}

Sub-populations of permittees and private operators were described and contrasted in terms of the personal attributes of managers and production strategies and resources of operations. Means were compared between sub-populations using $95 \%$ confidence intervals (95\% CI).

Four-celled contingency tables were used to depict fidelity of operators to active and passive categories of coping strategies between 1992/3 and 1996/7. The Chi Square test was used to compare year $\mathrm{x}$ strategy distributions between permittees and private operators.

As previously noted, several survey questions involved ranking exercises. These prominently included having opera- 
tors rank: (1) 3 factors that most influenced their choice of coping strategy; and (2) 3 priorities for applied research most relevant to their production problems. We opted for a descriptive approach for analyzing ranking data because of a high number of empty data cells; i.e., many respondents volunteered top-ranked responses but often failed to give secondand/or third-ranked responses. We analyzed these data by scoring top-ranked responses as worth 3 points, secondranked responses as worth 2 points, thirdranked responses as worth 1 point, and then adding ranking points for each factor or priority across all respondents. The relative importance of each factor or priority was merely based on the total ranking points as a proportion of the grand total.

We used a logistic regression package (SPSS 1992) to reveal factors statistically associated with active operations in 1996-7. Logistic regression was used because it can combine continuous and discrete information in the same analysis (Hosmer and Lemeshow 1989). We had 1 discrete response variable (i.e., active versus passive) and 9 possible explanatory factors that were discrete or continuous.

The 9 factors were first examined for problems of multi-colinearity, but this was not evident $(P>0.05)$. All 35 pairs of discrete factors had Spearman's correlation coefficients $<0.34$, while the 1 pair of continuous factors had a Pearson's correlation coefficient $<0.03$. Bohrnstedt and Knoke (1994) recommend deletion of factors due to risk of multi-colinearity only when correlation coefficients exceed 0.80 . We therefore proceeded with the 9-factor analysis.

The logistic model was sequentially built from the 9 factors based on previously introduced theory. Factors were added in order of their presumed importance (i.e., higher to lower) in explaining active management behavior. Ordering is important because sequential interaction among factors can influence $\mathrm{P}$ values in the final model. The ordering was: (1) INCOME; (2) DEBTABLE; (3) DEBTWILL; (4) PERINC; (5) PUBLIC; (6) LANDSUIT; (7) EDUCATE; (8) AGE; and (9) SOCIORGS. The first 4 reflected economic issues thought pre-eminent in promoting investment, while the fifth and sixth reflected resource tenure and quality. The last 3 reflected important personal characteristics of operators (Rogers 1983), but we anticipated less variability in these features among the producer population. Despite the emphasis on ordering, it is fair to say that the logistic analysis had an exploratory character given the dearth of similar work in rangeland systems (Coppock and Birkenfeld 1999).

The ranking method and logistic regression offered complementary approaches to address the important question of why active or passive coping strategies are pursued. The logistic regression offered a more objective analysis, but it's utility could be limited if critical explanatory factors happened to be omitted or misrepresented in the data. Conversely, while ranking exercises were limited by subjectivity of respondents, the spontaneity afforded by open-ended questioning could reveal new insights.

\section{Results}

\section{Attributes of Sub-Populations}

We obtained data from permittees and private operators living in all 29 Utah

Table 1. Descriptive attributes $(\bar{x} \pm 95 \%$ CI $)$ of the operator and management strategy for 2 categories of Utah grazing livestock producers, 1992-7.

\begin{tabular}{|c|c|c|c|}
\hline Attributes & Permittees $^{1}$ & Private Operators $^{2}$ & $\mathrm{P}$ \\
\hline \multicolumn{4}{|l|}{ Operator } \\
\hline Age (yr) & $56 \pm 1.8$ & $59 \pm 1.8$ & NS \\
\hline Time managing operation $(\mathrm{yr})$ & $28 \pm 2.4$ & $23 \pm 2.0$ & $*$ \\
\hline Formal education $^{3}$ & $2.7 \pm 0.2$ & $3.1 \pm 0.2$ & NS \\
\hline Social memberships ${ }^{4}$ & $2.0 \pm 0.8$ & $2.1 \pm 0.2$ & NS \\
\hline Confidence in future $^{5}$ & $3.6 \pm 0.2$ & $3.2 \pm 0.2$ & NS \\
\hline Commitment to operation $^{6}$ & $4.3 \pm 0.2$ & $3.8 \pm 0.2$ & NS \\
\hline \multicolumn{4}{|l|}{ Management Strategy } \\
\hline Profit oriented $(\%)^{7}$ & $45 \pm 6$ & $31 \pm 6$ & $*$ \\
\hline Hobby oriented $(\%)^{7}$ & $22 \pm 4$ & $41 \pm 6$ & $*$ \\
\hline Profit and hobby oriented $(\%)^{7}$ & $27 \pm 4$ & $24 \pm 6$ & NS \\
\hline Passive managers $(\%)^{8}$ & $70 \pm 4$ & $90 \pm 4$ & $*$ \\
\hline Plan to retire $(\%)$ & $28 \pm 4$ & $51 \pm 6$ & $*$ \\
\hline Other inertia $(\%)^{9}$ & $39 \pm 6$ & $37 \pm 6$ & NS \\
\hline Focus off-ranch $(\%)^{10}$ & $3 \pm 2$ & $2 \pm 2$ & NS \\
\hline Active managers $(\%)^{8}$ & $30 \pm 4$ & $10 \pm 4$ & $*$ \\
\hline Intensifiers $(\%)^{11}$ & $16 \pm 4$ & $4 \pm 2$ & $*$ \\
\hline Diversifiers $(\%)^{12}$ & $4 \pm 2$ & $2 \pm 2$ & NS \\
\hline Extensifiers $(\%)^{13}$ & $10 \pm 2$ & $4 \pm 2$ & $*$ \\
\hline
\end{tabular}

*Significant at the 0.05 level.

${ }^{1}$ Sample sizes ranged from 192 to 340 respondents.

${ }_{3}^{2}$ Sample size was 201 respondents.

${ }^{3}$ Level of formal education was scaled as 1 ( $<12$ years of schooling); 2 (high school graduate); 3 (vocational training after high school); and 4 (attended college).

${ }_{5}^{4}$ Level of social memberships was scaled as: 1 (0); 2 (1 to 3); 3 (4 to 6); and 4 (>6).

${ }^{5}$ Confidence was scaled as: 1 (very unconfident); 2 (somewhat unconfident); 3 (neutral); 4 (somewhat confident); and 5 (very confident).

${ }^{6}$ Commitment was scaled as: 1 (very uncommitted); 2 (somewhat uncommitted); 3 (neutral); 4 (somewhat committed); and 5 (very committed)

Respondents selected 1 answer that best described their goal of managing livestock. "Hobby" implies that livestock were raised more for lifestyle reasons and ancillary income generation compared to a profit-minded, business orientation.

${ }^{8}$ Passive managers were those who anticipated selling or transferring property, lacked resources to implement change, saw no need to change management from traditional practices, were cutting back on production inputs, etc. Active managers were those who were engaged in intensifying, diversifying, or extensifying (i.e., expanding) their grazing operations.

9"Other inertia" largely consisted of those who lacked resources to change, saw no need to change, or were cutting back on inputs.

${ }^{10}$ Typically an off-ranch focus involved diversifying into more off-ranch employment.

${ }^{11}$ Intensifiers were investing in property or animals to increase per unit productivity.

${ }^{12}$ Diversifiers were creating new income-earning opportunities on-ranch.

${ }^{13}$ Extensifiers were expanding by buying or leasing more land.

Sources: Birkenfeld (1994), Peterson (1997), and Coppock and Peterson (unpubl., 1998). 


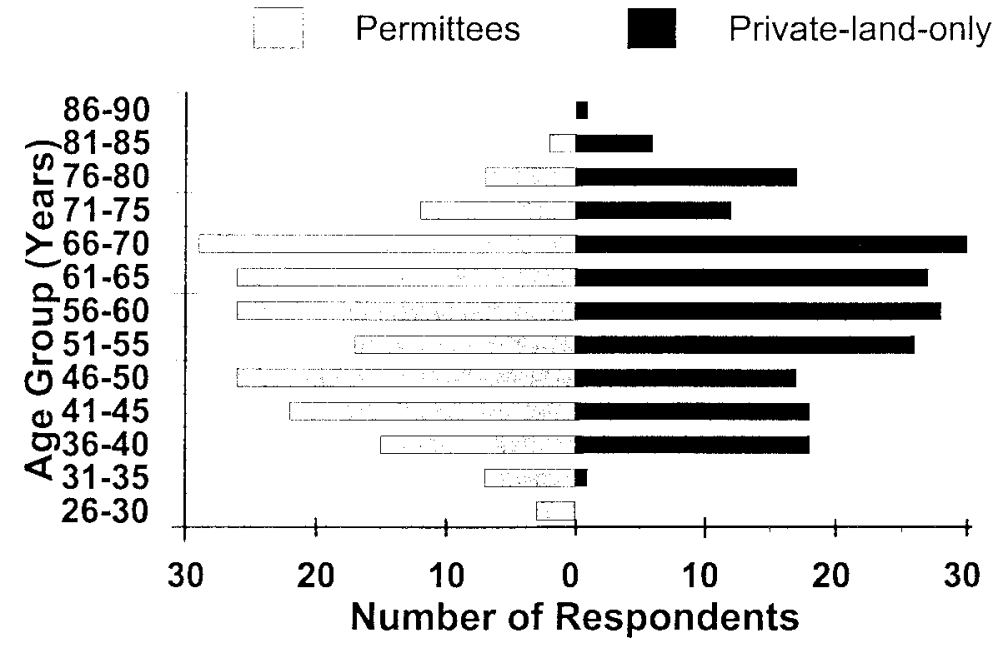

Fig. 1. Age distribution for land managers who were public grazing permittees $(n=192)$ or operators with a sole dependence on private grazing resources (e.g., private operators; $\mathbf{n}=$ 201) in Utah during 1996-7.

and management strategies (Table 1). Permittees were significantly more profitoriented than private operators, while the latter were twice as likely to be hobby-oriented. Managerial passivity was very high for both groups in 1996-7. The major difference was in terms of pending retirements-almost twice as many private operators had plans for imminent retirement compared to that for permittees. Permittees were 3 times more likely than private operators to be active managers, a difference largely attributable to a higher occurrence of permittees who were intensifiers and extensifiers (Table 1).

Differences were also evident between the 2 groups when considering primary sources of income and operation scale (Table 2). On a relative basis, permittees reportedly received nearly 3 times as much livestock-derived income than private operators; consequently, permittees had a lower relative dependence on offranch income. On average, permittees had much larger operations than did private operators. Permittees averaged 15 times more private grazing land, 3.6 times more irrigable grazing land, 3 times more cropland, 5.6 times more beef cattle, and over 16 times more sheep.

Cuts in AUMs on public grazing land were reported by permittees for 1993-6. Forty-two operators (or $22 \%$ of the 192) had experienced cuts in AUMs. These cuts were usually relatively minor and temporary, however, due to local drought or loss of forage from wildfire. These cuts were not interpreted to be due to any major shift in public grazing policies.

\section{Temporal Patterns of and Reasons for Coping Strategies}

Temporal patterns in coping strategy are shown as contingency tables in Figure 2 (a-c). The pattern for permittees differed from that of private operators $(\mathrm{P}<0.05$, $\mathrm{df}$ $\left.=3, \mathrm{X}^{2}=10.3\right)$; this was largely attributable to a higher number of private operators being consistently passive compared to permittees. When both groups were combined, $76 \%$ of respondents were consistently passive, $9 \%$ were consistently active, and $15 \%$ varied their strategies.

Reasons given by respondents for selecting coping strategies are shown in Table 3. These are largely self-explanatory. It was somewhat surprising, however, to see " a d v a n c i n g age/declining health" so commonly mentioned as a justification for passive coping strategies. Passivity was also often justified on the basis of economic constraints such as low beef prices and low returns on investment in grazing operations.

Our logistic regression model was significant overall at $\mathrm{P}<$ 0.001 . Out of 9 factors, however, only 4 were statistically significant $(\mathrm{P}<0.05)$. Our results indicated that micro-economic factors, community stewardship, and public-land dependence were significantly associated with active coping strategies (Table 4). The 5 factors not included in the final model were PERINC $(\mathrm{P}=0.49)$, EDUCATE $(\mathrm{P}=0.31)$, DEBTABLE $(\mathrm{P}=$ $0.30)$, AGE $(P=0.18)$, and LANDSUIT $(\mathrm{P}=0.13)$.

\section{Priorities for Applied Research}

Producer priorities for applied research are displayed in Table 5. Variation between permittees and private operators was minimal so results were combined. These results are largely self-explanatory, but somewhat paradoxical in light of findings on coping strategies. For example, despite that only a small minority (i.e., 10 $\pm 1 \%$ ) of all operators were "intensifiers" seeking to increase carrying capacity on private grazing land, the dominant research priority expressed by both permittees and private operators was work devoted to pasture or forage improvements.

\section{Discussion}

\section{Permittees vs. Private Operators}

Perhaps the most important similarity among permittees and private operators was their demographic profiles. That $37 \%$ of all operators were age 66 or older is an important finding and confirms statistics for Utah farmers and ranchers previously reported by Godfrey (1992). The phenomenon of low recruitment among agricultural producers is not unique to Utah-the mean age of agricultural producers has

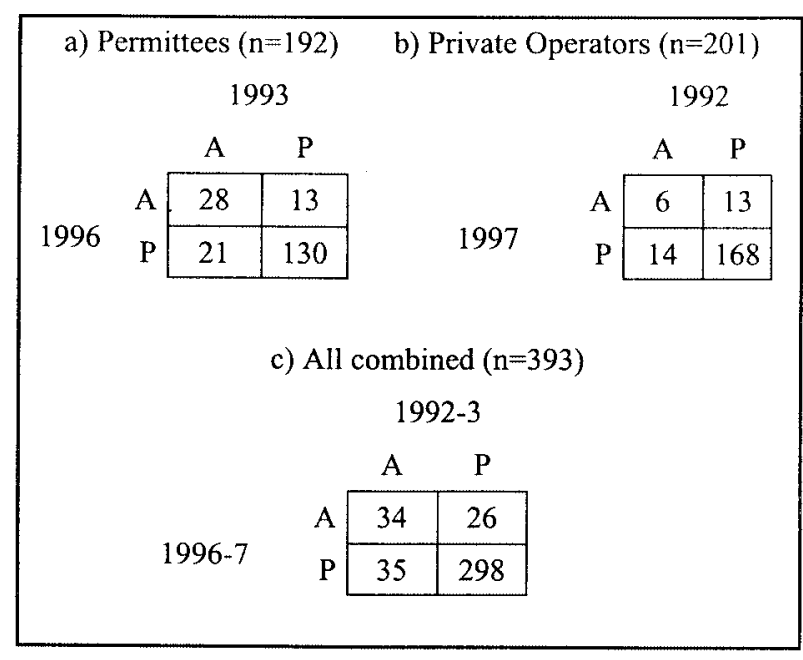

Fig. 2 (a-c). Temporal patterns for active (A) and passive (P) management behavior for public grazing permittees and operators soley dependent on private grazing resources, 1992-7, in Utah. 
Table 2. Descriptive attributes $\bar{x} \pm 95 \%$ CI $)$ of the land, labor, and capital for 2 categories of Utah grazing livestock producers, 1992-7.

\begin{tabular}{|c|c|c|c|}
\hline Attributes & Permittees $^{1}$ & Private Operators $^{2}$ & $\mathrm{P}$ \\
\hline \multicolumn{4}{|l|}{ Labor and Financial } \\
\hline Annual labor from household $(\%)^{3}$ & $85 \pm 2.6$ & $93 \pm 2.8$ & $*$ \\
\hline \multicolumn{4}{|l|}{ Gross annual income } \\
\hline Total $^{4}$ & $2.4 \pm 0.2$ & $2.6 \pm 0.2$ & NS \\
\hline From livestock $(\%)^{5}$ & $49 \pm 3.6$ & $17 \pm 3.0$ & $*$ \\
\hline From crops $(\%)^{5}$ & $6 \pm 1.4$ & $6 \pm 1.8$ & NS \\
\hline From wildlife $(\%)^{5}$ & $<1$ & $<1$ & NS \\
\hline From off-ranch $(\%)^{5}$ & $45 \pm 3.8$ & $76 \pm 4.0$ & $*$ \\
\hline Credit access $^{6}$ & $2.1 \pm 0.2$ & $2.1 \pm 0.2$ & NS \\
\hline Willingness to assume debt ${ }^{7}$ & $2.5 \pm 0.2$ & $2.2 \pm 0.2$ & NS \\
\hline Ability to assume $\mathrm{debt}^{7}$ & $3.3 \pm 0.2$ & $3.5 \pm 0.2$ & NS \\
\hline \\
\hline \multicolumn{4}{|l|}{ Deeded grazing land ${ }^{8}$} \\
\hline Total (ac) & $2,428 \pm 544.0$ & $166 \pm 88.0$ & $*$ \\
\hline Irrigable (ac) & $177 \pm 43.2$ & $49 \pm 19.6$ & $*$ \\
\hline Deeded cropland (ac) & $164 \pm 41.6$ & $60 \pm 19.0$ & $*$ \\
\hline Grazing land suitability $^{9}$ & $3.5 \pm 0.2$ & $3.9 \pm 0.2$ & NS \\
\hline Beef cows (hd) & $141 \pm 13.8$ & $25 \pm 4.5$ & $*$ \\
\hline Other beef cattle (hd) ${ }^{10}$ & $95 \pm 52.2$ & $17 \pm 4.1$ & NS \\
\hline Sheep (hd) ${ }^{11}$ & $212 \pm 56.6$ & $13 \pm 5.2$ & $*$ \\
\hline Public grazing AUMs $(\%)^{12}$ & $39 \pm 1.4$ & NA & \\
\hline \\
\hline \multicolumn{4}{|c|}{${ }_{2}^{1}$ Sample sizes ranged from 192 to 340 respondents. } \\
\hline \multicolumn{4}{|c|}{${ }^{2}$ Sample size was 201 respondents. } \\
\hline \multicolumn{4}{|c|}{$\begin{array}{l}{ }^{3} \text { Percent annual labor requirements for the operation as met by household (i.e., family) members was estimated by } \\
\text { respondents. }\end{array}$} \\
\hline \multicolumn{4}{|c|}{$\begin{array}{l}4 \text { Total gross annual income was scaled as: } 1(\leq \$ 25,000) ; 2(\$ 25,001 \text { to } \$ 40,000) ; 3(\$ 40,001 \text { to } \$ 60,000) ; 4(\$ 60,001 \text { to } \\
\$ 100,000) \text {; and } 5(>\$ 100,000) \text {. } \\
5 \text { Percent gross annual income derived from livestock, crops, wildlife, or off-ranch sources was estimated by respondents. }\end{array}$} \\
\hline \multirow{2}{*}{\multicolumn{4}{|c|}{$\begin{array}{l}5 \text { Percent gross annual income derived from livestock, crops, wildlife, or off-ranch sources was estimated by respondents. } \\
6 \text { Credit access was scored as: } 1 \text { (an open line); } 2 \text { (credit is accessible if the investment is justified to the lender); } 3 \text { (opera- } \\
\text { tor is typically unqualified to receive credit); } 4 \text { (credit has never been sought to improve the operation). }\end{array}$}} \\
\hline & & & \\
\hline \multicolumn{4}{|c|}{$\begin{array}{l}7 \text { Debt characteristics were scaled as: } 1 \text { (very unwilling/unable); } 2 \text { (somewhat unwilling/unable) } 3 \text { (neutral); } 4 \text { (somewhat } \\
\text { willing/able); and } 5 \text { (very willing/able). }\end{array}$} \\
\hline \multicolumn{4}{|c|}{$\begin{array}{l}{ }^{8} \text { Tabulated figures focus on owned property because it was thought that owned property is more liable to be better man- } \\
\text { aged or improved. Land leasing is common, however, especially among private-land-only operators. The typical length } \\
\text { of leases was } 1 \text { year. }\end{array}$} \\
\hline \multirow{4}{*}{\multicolumn{4}{|c|}{$\begin{array}{l}{ }^{9} \text { Suitability of owned grazing land for technical improvements in general as judged by the respondent. Suitability was } \\
\text { scaled as: } 1 \text { (very unsuitable); } 2 \text { (somewhat unsuitable); } 3 \text { (neutral); } 4 \text { (somewhat suitable); and } 5 \text { (very suitable). } \\
{ }^{10} \text { Other beef cattle included stockers and yearlings being fattened. } \\
{ }^{11} \text { Mean holdings of sheep for permittees is misleading. A few permittees manage thousands of sheep while the majority } \\
\text { have none. Sixty-seven permittees out of } 340 \text { surveyed managed sheep. }\end{array}$}} \\
\hline & & & \\
\hline & & & \\
\hline & & & \\
\hline \multicolumn{4}{|c|}{${ }^{12}$ The percent of AUMs on public grazing was calculated by Birkenfeld (1994). } \\
\hline & & & \\
\hline
\end{tabular}

ducers. This was illustrated by the smaller size of their operations, income strongly skewed toward off-ranch sources, and their predominant objective for livestock husbandry was more related to hobby incentives (i.e., lifestyle factors and generation of ancillary income). Although permittees are very diverse in socioeconomic terms [i.e., nearly $50 \%$ of permittees are also hobbyists (Coppock and Birkenfeld 1999)], on average permittees were more profit-driven and dependent on livestockrelated income compared to private operators. Although permittees and private operators were very similar in terms of overall number of operations, permittees controlled about $93 \%$ of private grazing land, $85 \%$ of the beef cattle, and $94 \%$ of the sheep. When isolating resource control based on production motivation, regardless of public-land dependence, it is notable that operations run by persons with hobby incentives controlled about $20 \%$ of private grazing land and $20 \%$ of grazing livestock. Producers whose motivations were dominated by hobby incentives added to $32 \%$ of the target population-if producers with any hobby incentive are added this subgroup increases to $62 \%$ of the target population. The findings that hobbyists make up a large proportion of the producer population and control significant amounts of animal and land resources are important because other work indicates, compared to purely profitdriven producers, that hobbyists are less inclined to adopt recommended range and livestock management practices (Coppock and Birkenfeld 1999). been rising in western states over the past 30 years (Donald Snyder and Richard Wilde, USU, unpubl. data, 1992; Donald Snyder, USU, pers. comm., 1999). Low recruitment is attributable to changing career incentives and declining profitability and increasing risk for family-based operations. Continuity is also limited by high initial investment costs for contemporary operations. Down-payments ranging from onethird to one-half of total property value are common and often pose insurmountable barriers to younger people hoping to enter agricultural professions (Donald Snyder, USU, pers. comm., 1999).

There were marked differences between permittees and private operators in terms of resource control and motivation for involvement in grazing livestock production. Private operators, in general, are best described as truly part-time livestock pro-
Table 3. Priority reasons given by 393 randomly selected grazing livestock producers in Utah regarding why they have chosen active versus passive management strategies, 1996-7 ${ }^{1}$.

\begin{tabular}{lcc}
\hline \hline Priority Reason & Ranking Points & Percent \\
\hline For Being an "Active" Manager & 116 & 42 \\
Increase profitability, productivity & 72 & 26 \\
Maintain lifestyle, value good management & 45 & 16 \\
Expect loss of access to public land grazing & $\underline{43}$ & $\underline{16}$ \\
Other (7 reasons combined) & 276 & 100 \\
$\quad$ Total & 546 & 43 \\
For Being a "Passive" Manager & 443 & 35 \\
Retirement ${ }^{2}$, aging, poor health & 147 & 12 \\
Economic constraints & 81 & 6 \\
Change not needed & 46 & $\underline{4}$ \\
Land constraints & & 100 \\
Other (3 reasons combined) & 1,263 & \\
$\quad$ Total & & \\
\hline
\end{tabular}

${ }^{\mathrm{B}}$ Based on rankings where respondents volunteered up to 3 priority reasons each. The top priority received 3 ranking points, the second received 2, and the third received 1 . This system should have yielded 2,358 total ranking points (i.e., 6 x 393). On average, however, respondents only gave 1 or 2 reasons.

Specifically, "estate planning" was often mentioned as a primary retirement concern that led to passive management behavior.

${ }^{3}$ Low beef prices, low rate of return on investment in beef grazing operations, etc.

${ }^{4}$ Low availability of private grazing land; urban/rural conflicts, etc.

Sources: Peterson (1997), Coppock and Peterson (unpubl., 1998) 
Table 4. Logistic regression results for factors associated with active management behavior among 393 randomly selected grazing livestock producers in Utah, 1996-7 ${ }^{1}$.

\begin{tabular}{lcc}
\hline \hline Factor & Beta Coefficient $^{2}$ & Odds Ratios $^{3}$ \\
\hline Total Gross Annual Income (INCOME) & Od $^{4}$ & $1.49^{* *}$ \\
Ability to Assume Debt (DEBTABLE) $^{5}$ & 0.40 & 1.15 \\
Willingness to Assume Debt (DEBTWILL) $^{5}$ & 0.14 & $1.35^{* *}$ \\
Percent Income from Off-Ranch (PERINC) $^{6}$ & 0.30 & 1.00 \\
Public Land Dependence (PUBLIC) $^{7}$ & 0.01 & $3.80^{* * *}$ \\
Land Suitability (LANDSUIT) $^{5}$ & 1.33 & 1.23 \\
Formal Education (EDUCATE) $^{8}$ & 0.21 & 1.24 \\
Age (AGE) $^{9}$ & 0.22 & 0.98 \\
Social Memberships (SOCIORGS) $^{10}$ & -0.02 & $2.04 * *$ \\
\hline
\end{tabular}

******Significant at the 0.01 and 0.001 levels, respectively.

${ }^{1}$ Nine social, economic, and resource factors were used in this analysis. After identifying the 4 significant factors above, the analysis was re-run to include interactions among significant factors. No interactions were significant, however.

${ }^{2}$ The beta coefficients are used in the regression model as follows:

$$
\pi(\mathrm{x})=\frac{\exp [\mathrm{g}(\mathrm{x})]}{1+\exp [\mathrm{g}(\mathrm{x})]}
$$

where $(\mathrm{x})$ is the "likelihood of being active" and $\mathrm{g}(\mathrm{x})=-7.09+0.40($ INCOME $)+0.14($ DEBTABLE $)+$ $0.30($ DEBTWILL $)+0.01($ PERINC $)+1.33($ PUBLIC $)+0.21($ LANDSUIT $)+0.22($ EDUCATE $)-0.02($ AGE $)+$ 0.72 (SOCIORGS)

${ }^{3}$ The odds ratios give the increase in the likelihood that an operator will be an active manager with each level unit of increase in a given factor. For example, as "willingness to assume debt" increased 1 level from among "very unwilling", "somewhat unwilling", "neutral", "somewhat willing", and "very willing", the odds an operator would be active increased by $35 \%$.

${ }^{4}$ Income levels were scaled as: $1(\leq \$ 25,000) ; 2$ (\$25,001 to $\left.\$ 40,000\right) ; 3(\$ 40,001$ to $\$ 60,000) ; 4(\$ 60,001$ to $\$ 100,000)$; and $5(>\$ 100,000)$.

${ }^{5}$ Debt and land suitability factors were variously scaled as: 1 (very unwilling/unable/unsuitable); 2 (somewhat unwilling/unable/unsuitable); 3 (neutral); 4 (somewhat willing/able/suitable); and 5 (very willing/able/suitable).

${ }^{6}$ Percent gross annual income earned from off-ranch sources was estimated by respondents.

${ }^{7}$ Public land dependence was scaled as: 1 (private operators: zero dependence) or 2 (permittee: some dependence). A permittee was about 3-times more likely to be an active manager compared to a private operator, but in absolute terms active managers were in a minority (i.e., $10 \%$ versus $30 \%$ for private operators and permittees, respectively).

${ }^{9}$ Age in years as provided by respondents

${ }^{10}$ Level of social memberships were scaled as: 1 (0); 2 (1 to 3$) ; 3$ (4 to 6); and 4 (>6).

Source: Ralls, Peterson, and Coppock (unpubl., 1998).

\section{Active vs. Passive Management}

Compared to being a private operator, being a permittee did have a positive effect on incidence of active management behavior. While this empirical result confirmed one of our hypotheses, the primary cause of active behavior did not appear to be what we expected, namely fear of permittees that they would lose access to public grazing. Rather, the dominant factor seems to be the heightened entrepreneurial orientation of permittees in general compared to private operators. This was interpreted from the ranked responses of operators in conjunction with other data (Peterson 1997) indicating permittees overwhelmingly make planning and management decisions based on economicnot political-criteria.

Averaged across permittees and private operators, those who classified themselves as passive managers by 1996-7 comprised a surprising $80 \%$ of the population. Overall, pending retirement was a major component of passivity. This looming crest in turnover of land managers has important implications for land use. For example, $43 \%$ of permittees planning to retire wanted to sell their properties to land developers, while $57 \%$ wanted to keep operations in the family (Peterson
Sleight, USU, pers. comm., 1999). Incentives to help farm and ranch families keep properties intact and under agricultural use across generations are often undermined by desires of retirees and their heirs to cash-out. Even if an heir wants to keep an operation going, a sale is typically forced by other family members (Weldon Sleight, USU, pers. comm., 1999).

Change in land use offers new challenges for range research and resource management. If it is assumed, for example, that land development implies creation of residential areas dominated by "ranchettes," emerging problems of resource fragmentation and dominance of hobby-motivated livestock producers could prevail in these areas. We speculate that the remainder of private grazing lands kept in more traditional forms of land use would ultimately be managed by fewer, wealthier individuals as economic shakeouts claim more victims. Such a trend could be favorable for some aspects of natural resource management, however, as wealthier individuals managing larger operations appear more able to implement innovative resource management plans compared to those with lower incomes and smaller operations (Harris et al. 1995, Coppock and Birkenfeld 1999).

Overall, the percentage of operations carrying out intensification tactics was $10 \%$, suggesting that approximately 500 operations were involved in absolute terms. Of this 500 about 100 had a focus on intensifying beef production through changes in animal-based feeding or breeding management (Peterson, unpubl. data, 1997; Coppock and Peterson, unpubl. data, 1998). Land-based intensification projects reported to us included: (1) converting irrigated alfalfa to irrigated pasture; (2) replacing shrubby upland vegeta-

Table 5. Priorities for applied research given by 393 randomly selected grazing livestock producers in Utah, 1996-7 ${ }^{1}$.

\begin{tabular}{lcc}
\hline \hline Research Priority & Ranking Points & Percent \\
\hline Pasture improvements $^{2}$ & 432 & 40 \\
Policy analysis $^{3}$ & 206 & 19 \\
Marketing, financial management $_{\text {Technology transfer }}$ & 107 & 10 \\
Resource management systems & 75 & 7 \\
Weed/pest control & 70 & 6 \\
Livestock health $_{\text {Other miscellaneous issues }}^{4}$ & 55 & 5 \\
$\quad$ Total & $\frac{92}{085}$ & 9 \\
\hline
\end{tabular}

${ }^{\mathrm{T}}$ Based on rankings where respondents volunteered up to 3 priorities each. The top priority received 3 ranking points, the second received 2, and the third received 1. This system should have yielded 2,358 total ranking points (i.e., $6 \mathrm{x}$ 393). On average, however, respondents only gave 1 priority.

2 "Pasture" should be broadly interpreted to mean forage improvements relevant to both irrigated and rain-fed conditions.

${ }^{3}$ Land use, urban/rural conflicts, environmental regulations, trade policy, etc.

4Included a number of poorly defined "agricultural" and "personal" issues as well as public education themes.

Sources: Peterson (1997) and Coppock and Peterson (unpubl., 1998). 
tion with improved grasses after plowing, burning, and/or chemical treatment; (3) expanding forage grasses under irrigation; (4) improving irrigation and fencing systems; (5) introducing new forages to wet meadows; (6) leveling land and improving irrigation on wet meadows; and (7) improving and expanding native grass and alfalfa hayfields (Peterson 1997, Coppock and Peterson, unpubl. data, 1998).

Results from logistic regression and ranking exercises revealed operators able to carry out intensification plans were those with a combination of higher gross annual incomes, stewardship values, and a greater willingness to assume debt in support of production improvements. We interpret willingness to assume debt as indicative of a higher risk tolerance characteristic of wealthier operators. Wealthier operators can afford to be less concerned about marginal returns from investment in grazing operations [on the order of $2 \%$ (Capps and Workman 1982)] and some may even be able to indulge in a few landmanagement "whims" that may not be justified purely on an economic basis. As another testimony to the role of wealth in promoting investment in private grazing lands, most of our "intensifiers" were not looking for means to co-finance or subsidize their projects. This was despite costs estimated between $\$ 5,000$ and $\$ 250,000$ per project by respondents (Peterson 1997). Our work confirmed the view of Rogers (1983) that wealth is a reliable predictor of innovative, risk-tolerant behavior.

Attempts to diversify operations were relatively rare and comprised only $3 \%$ of all operations surveyed. Expert opinion endorses enterprise diversification as a major risk management strategy under economic stress (Larry Butler, NRCS, pers. comm., 1997). Our findings confirm earlier work (Coppock and Birkenfeld 1999) that only a very small number of private operators and permittees in Utah are considering economic diversification.

Attempts to expand operations were also rare and comprised only $7 \%$ of all operations surveyed. Managers who focused on expansion of operations were among the wealthiest of all survey respondents (Peterson 1997).

\section{Dynamics of Coping Strategies}

Our results lead us to reject the hypothesis that active management behavior was on a sustained upswing during the 1990s. Our observations instead supported the alternative hypothesis that managerial passivity was maintained-or even increased-across the population overall.
Why should passivity be maintained? We suspect that a combination of macroand micro-level factors explain observed patterns. First, it was evident that implementation of policy reforms on most public grazing lands in Utah had not occurred by 1996, as evidenced by the lack of permanent cuts in AUMs for permittees in our sample. In addition, intense public debate on "Range Reform" appeared to wane by the mid-1990s (D.L. Coppock, pers. obs., 1998). These trends probably compelled many permittees to shelve plans they had for intensification, especially if other socioeconomic factors on the horizon appeared unfavorable.

We speculate that widespread adoption of novel technology and management systems for private grazing lands could have occurred if beef prices remained high, pressure to reduce access to public grazing had increased, and the average producer was further from retirement age. With a sustained drop in real beef prices since 1995 , however, it is unlikely that producers would have been able to secure the financing for substantive production improvements (DeeVon Bailey, USU, pers. comm., 1999). Widespread enthusiasm for interventions such as irrigated pasture improvements in the early 1990s was probably a result of an initial overreaction by producers to Range Reform rhetoric (D.L. Coppock, pers. obs., 1998) in combination with optimism engendered by high profits enjoyed by beef operations during 1988-94 (DeeVon Bailey, USU, unpubl. data, 1999).

Perhaps our most important observation was that operators perceived the combination of their advancing age and declining health as the greatest impediment to active management behavior. "Declining health" was discovered from the open-ended ranking questions - age per se was not significant $(\mathrm{P}=0.18)$ in the logistic regression. Despite awareness that the average age of agricultural producers is increasing in the western US (above), the obvious consequences that aging has for resource management and technology transfer are not apparent from the literature. It certainly makes sense that as producers near retirement they put more resources into estate planning to the detriment of investing in their production systems.

For new technology or information to have maximum utility, demographic and economic factors need to be in a favorable alignment. For example, a younger population of wealthier operators responding to growing markets for livestock products would represent such an alignment.
Factors could be integrated into a stateand-transition model for human management behavior much like that proposed for describing vegetation dynamics on arid rangelands (Westoby et al. 1989). Similarly, rates of adoption of relatively expensive technology and management systems could be expected to follow more of an episodic or ephemeral pattern coincident with favorable and sustained alignment of economic and demographic variables. This concept is unlike the traditional sigmoid curve model proposed for many forms of technology diffusion where technology adoption is a cumulative and continuous process (Rogers 1983).

Considering our findings overall, the patterns we observed support contentions that local innovation in contemporary agricultural systems is constrained more by macro- or micro-level economic and demographic phenomena rather than lack of technology or information (Boserup 1965, Holechek et al. 1994, Udo and Cornelissen 1998). Conversely, when economic and demographic factors are favorable, key technology or information can be more rapidly taken up and change can result. Understanding the difference between the 2 scenarios is important. It is illuminating to note that managerial passivity was never justified by our respondents because of a lack of extension information or production technology. In this case, producer inertia would not be overcome with more extension information.

Finally, survey respondents indicated that technical (i.e., forage-related) and social (i.e., policy, economics) research were both relevant to their priority problems. Given the low percentage of intensifiers in our target population, we were somewhat surprised that forage research would still be regarded as the highest research priority. This finding confirmed previously cited anecdotal observations that producer interest in irrigated pasture and related topics is real. We reconcile these views by speculating that producers see ongoing forage research as useful to mitigate future risks. For example, should the time come when a majority of operators are suddenly forced to invest in private grazing lands, they want relevant technology to be available.

\section{Conclusions}

Macro- and micro-level economics and producer demographics are the major constraints for increased investment in Utah 
private grazing lands at the present. The joint occurrence of favorable economic and demographic factors, in conjunction with resource pressure, drives change in land management and demand for technology and information in an episodic fashion. Operations most likely to be in a continuous process of active management, investment, and innovation are the minority having more financial resources, stewardship ethics, and tolerance of risk. A looming crest in retirement among permittees and private operators is currently having a negative effect on investment in Utah private grazing lands.

Applied research and extension should prepare now to meet new challenges afforded by pending changes in land use and land users. Applied research and extension need to act with a degree of opportunism to improve response to rapid change. If it is assumed that helping sustain traditional forms of land use is desirable in some cases, more attention to innovation in policy formulation and public education is needed to achieve this end. Broad-based efforts that collectively encourage younger people to stay on the land would address a cornerstone of the problem.

\section{Literature Cited}

Anderson, V.J. 1989. Land status in Utah, p. 57-73. In: K.L. Johnson (ed)., Rangeland resources of Utah. Coop. .Ext. Serv., Utah State Univ., Logan, Ut.

Birkenfeld, A.H. 1994. Diversity and innovation adoption among Utah public land permittees. Master's thesis, Utah State Univ., Logan, Ut.

Bohrnstedt, G.W. and D. Knoke. 1994. Statistics for social data analysis $\left(3^{\text {rd }}\right.$ Ed.). F. E. Peacock Publishers, Inc., Itasca, Il.

Boserup, E. 1965. The conditions of agricultural growth: The economics of agrarian change under population pressure. Aldine Publ. Co., New York, N.Y.

Capps, T.L. and J.P. Workman. 1982. Management, productivity, and economic profiles of two sizes of Utah cattle ranches. Utah Agr. Exp. Sta. Rep. 69. Utah State Univ., Logan, Ut.

Coppock, D.L. and A.H. Birkenfeld. 1999. Use of livestock and range management practices in Utah. J. Range Manage. 52:7-18.

Godfrey, E.B. 1992. The beef industry in the economy of Utah. Utah Agr. Exp. Sta. Rep. 143. Utah State Univ., Logan, Ut.

Harris, T.R., A. Battacharyya, W.G. Kvasnicka, and G.M. Veserat. 1995. What type of rancher looks for new technology? Rangelands 17:217-221.
Holechek, J.L., J. Hawkes, and T.D. Darden. 1994. Macroeconomics and cattle ranching. Rangelands 16:118-123.

Hosmer, D.W., and S. Lemeshow. 1989. Applied logistic regression. John Wiley \& Sons, New York, N.Y.

Peterson, R.S. 1997. Coping strategies of Utah grazing permittees under economic and social pressure. Master's thesis. Utah State Univ., Logan, Ut.

Rogers, E.M. 1983. Diffusion of innovations $\left(3^{\text {rd }}\right.$ Ed.). The Free Press, New York, N.Y.

Scheaffer, R.L., W. Mendenhall, and L. Ott. 1979. Elementary survey sampling (2nd Ed.). Duxbury Press, North Scituate, Ma.

SPSS (Statistical Package for the Social Sciences). 1992. SPSS ${ }^{\mathrm{TM}}$ for windows professional statistical release 5. SPSS Inc., Chicago, Ill.

Udo, H. and T. Cornelissen. 1998. Livestock in resource-poor farming systems. Outl. Agr. 27(4): 237-242.

Westoby, M., B. Walker, and I. Noy-Meir. 1989. Opportunistic management for rangelands not at equilibrium. J. Range Manage. 42:266-274.

Workman, J.P. 1994. Higher federal grazing fees-impacts on Utah ranches. Rangelands $16: 7-8$. 